\title{
Guideline for authors
}

The Journal for East European Management Studies is a refered journal, which aims to promote the development, advancement and dissemination of knowledge about management issues in Central and East European countries. The editors invite articles that are social science-based and address the general areas of Organisation and Management Studies, including Strategic Management, the Management of Change, Human Resources Management, Industrial Relations, International and Cross-Cultural Management and Business Ethics. Articles can cover all forms of indigenous enterprise within Central and Eastern Europe, as well as Western corporations that are active in this region. JEEMS welcomes papers that report the results of scientifically based empirical research into as well as theoretical contributions to recent developments in these areas. The journal encourages work from all methodological positions. In order to promote a true dialogue, papers authored by East European contributors or mixed East-West groups of researchers are especially welcome. All submissions are subject to double-blind review by a team of Eastern and Western academics.

JEEMS also publishes research notes for discussion of current research questions, as well as book reviews, reports on conferences and institutional developments with respect to management questions in Central and Eastern Europe. The editorial committee decides about the publication of those contributions.

In order to facilitate the journal's review and publication processes all contributors are advised to consider the following requirements carefully. Manuscripts that fail to meet these formal requirements may be rejected or returned for further drafting.

\section{Length/Size}

- All contributions must be prepared as files using Word for Windows.

- Articles should not exceed 8000 words (including references and tables); research notes should be 5000 words in maximum.

- They must be typed, double-spaced, on one side of A4, with margins of $2.5 \mathrm{~cm}$.

- Sheets should be numbered.

- Paragraphs should be connected without blank spacing.

- Optimal font size is Times New Roman 12pt or similar. 


\section{Language}

- Articles must be written in English. Contributors are required to use British English (i.e. not American English) spelling in the text.

- Research notes (exceptionally), reports and other contributions may be acceptable in German.

- All accepted papers will be language checked by a native speaker on the journal's editorial board. Nevertheless, it is the author's responsibility to present papers in an acceptable form, both in terms of grammar and expression, and should check their manuscript for typing errors, spelling, punctuation, etc.

- Abbreviations, if not used internationally, should be avoided.

\section{Title page}

Each article must be preceded by a title page which contains:

- the title,

- the names of the author or authors,

- the corresponding author's full postal and email addresses,

- the affiliation and main research interests of each author.

\section{First page}

The first page should start with the article's title, followed by

- an abstract of about 100 words (if possible in the English and German language),

- 4-6 keywords, and

- the main text of the paper.

In writing the paper, authors should take all reasonable steps to avoid information that clearly identifies them.

\section{Titles}

Main titles should be printed in bold types, secondary titles in bold and italics, tertiary only in italics.

\section{Footnotes}

Footnotes should be kept to a minimum and must be placed at the foot of the page to which they refer. They should not be used for citing references. 


\section{References in the text}

- Mentioning of author(s): Smith (1990) argues... or Smith and Miller (1990) argue... or Smith et al. (1990) argue...

- Reference to author(s): (Smith 1990) or (Smith/Miller 1990) or (Smith et al. 1990)

- Reference to different sources: (Miller 1985; Smith 1990) - in order of the year from older to more recent sources

Quotation of author(s): (Smith 1990:34) or (Smith/Miller 1990:34) or (Smith et al. 1990:34)

\section{Reference list}

All references must be listed at the end of the article or research note in alphabetical order of the first author's surname (no numbering) according to the following examples:

- Bartlett, C./Ghoshal, S. (1992): Managing across boarders. London: Century Business.

- Kozminski, A.J. (1995): From communist nomenklatura to transformational leadership: The role of management in the postcommunist enterprise, in: Grancelli, B. (ed.): Social change and modernization, Berlin: de Gruyter, 83-106.

- Clark, E./Lang, R./Balaton, K. (2001): Making the transition: Managers and management in transforming and reforming economies, in: International Studies of Management \& Organization, 31, 2, 3-8.

- World Bank (ed.) (2001): Annual report, Washington.

\section{Tables and figures}

- Tables as well as figures should be numbered consecutively with Arabic numerals and contain a short title. They must be placed on separate sheets at the end of the article. The author should mention where they should be placed in the text: e.g. Figure 4 to be placed about here.

- References to tables or figures in the text should refer to the number only: e.g. As can be seen in Table 3 resp. (see Figure 1)

- Figures should be designed in black and white only.

- The size of the lettering of the text should be in Times New Roman 12 throughout the figure.

- Figures should be saved as graphics or word data files.

- The size of tables and figures must not exceed one page of A4. 


\section{Review process:}

- Authors are required to submit a paper as an email attachment sent to the JEEMS co-ordinator.

- The editorial committee checks all submissions for consistency with the journal's general principles and mission. Papers found inappropriate will be immediately rejected.

- All submitted articles found appropriate will be subject to a double-blind review process, which includes a minimum of two anonymous reviewers, if possible from both a Western and a CEE country.

- If the reviewers require some revisions to be done, the authors must resubmit their revised paper together with an accompanying letter, which explains in detail how the authors have responded to the reviewers' comments.

- Contributions submitted as research notes do not undergo a double-blind review process. Instead the editorial committee will consider their appropriateness for publication.

- The editorial committee relies broadly on the reviewers' comments and decisions. However, especially where the reviewers make contrasting judgements, the editorial committee will take the final decision about acceptance or rejection.

\section{Submissions:}

All contributions and other editorial correspondence should be addressed electronically to the JEEMS co-ordinator:

Thomas Steger

University of Regensburg

Universitätsstr. 31

D-93053 Regensburg (Germany)

Email: thomas.steger@wiwi.uni-regensburg.de 